\title{
Teachers' perception of school violence in a sample from three european countries
}

\author{
José Jesús Gázquez Linares \\ Adolfo Javier Cangas Díaz \\ María del Carmen Pérez Fuentes \\ Francisca Lucas Acién \\ Universidad de Almería, España
}

The objective of the present study was to explore, in three European countries (Spain, Hungary and the Czech Republic), teachers' perception of the prevalence of different problematic aspects related to coexistence in schools, and of how they are personally affected by these aspects. The results reveal a high prevalence of fights, insults and demotivation/boredom in pupils, according to teachers in these three countries, and they also report pupils' demotivation/boredom as the aspect that most affects them personally. By countries, Spain and the Czech Republic present the highest rates of school violence, with Hungary showing significantly lower rates. Also, there are differences between the three countries analyzed as regards the prevalence and repercussions of a range of coexistence problems studied.

\section{Introduction}

In the last few years, in general, an increase in conflicts and violent behaviours among the young people has been observed (Krug, Dahlberg, Mercy, Zwi, \& Lozano, 2002). This is neither uniform in all the countries nor increases the same kinds of violence at the same level. In any case it seems that the bigger presence of this phenomenon can have an influence on the school environment which is in fact a reflection of all social conflicts and values (Smith-Khuri et al., 2004).

In this sense the studies that analyze the common and uncommon features of school violence among the different countries are important (Due et al., 2005; Smith, Morita, JungerTas, Olweus, Catalano, \& Slee, 1999).

In such a context, teachers play a fundamental role in the achievement of adequately harmonious coexistence and in the implementation of programmes for the prevention of violence (Dake, Price, Telljohann, \& Funk, 2003; Juvonen, Graham, \& Schuster, 2003; Newman-Carlson \& Horne, 2004; Orpinas, Horne, \& Multisite Violence Prevention Project, 2004; Yoon, 2004). Currently, despite the presence in the education system of optimistic and

This work forms part of a research project financed by the Commission for Education and Culture of the European Union (Ref. 112569-CP-1-2003-1-ES-COMENIUS-C21). 
enthusiastic teachers prepared to involve themselves in the solution of the problems, there is also an increase in the level of frustration, since they are faced with extremely difficult tasks, which they are scarcely qualified to deal with (Orpinas et al., 2004); the elimination of these problems requires a series of actions for which there is as yet no general formula, though the situation can be helped by the dissemination of all the accumulated knowledge on how to achieve an appropriate system of coexistence.

Violence and bullying are currently considered to be common to all countries (Smith et al., 1999), and are perceived by teachers as an obstacle to the achievement of an appropriate school climate. Therefore, in many cases where they are detected, measures are taken to deal with them (Fekkes, Pijpers, \& Verloove-Vanhorick, 2005), though 76\% of teachers believe in the need for some type of preventive action (Fisher \& Kettl, 2003).

Teachers also participate actively in bullying, on the one hand as aggressors: over $40 \%$ of pupils report having seen a teacher practice these behaviours on pupils, even though only $5 \%$ of pupils report being bullied by a teacher occasionally or frequently (Chapell et al., 2004); and on the other as victims, $66 \%$ of teaching staff reporting that women are more affected in these cases (Meyer, Astor, \& Behre, 2002).

The multiple studies (Chapell et al., 2004; Dake et al., 2003; Fisher \& Kettl, 2003; Spanish People's Ombudsman's Report, 2000) that take into account the opinion of teachers on the prevalence of behaviours affecting coexistence in their schools start out from different definitions, analyze different educational stages and use heterogeneous instruments (Crothers \& Levinson, 2004; Espelage \& Swearer, 2003; Griffin \& Gross, 2004; Solberg \& Olweus, 2003).

Thus, the aim of our work is to reveal, through the application of a single instrument in three different European countries, teachers' perceptions of the prevalence of behaviours that prevent harmonious coexistence in schools and the personal repercussions of these behaviours that disrupt school climate for the teachers themselves, which can take various forms.

To do so three countries with different social and educational system have been selected. One is Spain, a well-established country within the European Union, the others are Hungary and the Czech Republic, country that have been recently incorporated into the EU and that come from a different political system.

\section{Method}

\section{Participants}

The study sample was made up of 339 secondary school teachers from 10 Spanish schools, five Hungarian schools and five schools from the Czech Republic. By country, 137 teachers were from Spain, 133 were from Hungary and 69 were from the Czech Republic.

\section{Instrument}

Questionnaire on Difficulties for School Coexistence. This is an adaptation of Ortega and del Rey's (2003) questionnaire by Gázquez, Cangas, Padilla, Cano, and Pérez-Moreno (2005). This questionnaire has a total of 26 items and comprises two parts, each with 13 items. The items refer to 13 situations related to coexistence in schools. In the first part, teachers are asked to rate the extent to which the 13 situations are found in their schools, while in the second, they are asked to rate how far these same situations affect them personally. Each situation is rated on a four-point scale, in terms of its presence in the school: (a) high presence, (b) moderate, (c) slight, and (d) not at all. The 13 situations are: (1) Conflicts between pupils and teachers, (2) There are no clear norms of coexistence, (3) Bad language in class, (4) Pupils insult one another, (5) Pupils fight, (6) There are groups which don't get on, (7) There are pupils who are not integrated and feel alone, (8) Teachers just go about their own business, (9) Pupils think the teachers don't understand them, (10) Pupils are demotivated/bored, (11) Use or presence of weapons, (12) Use or presence of drugs; and (13) Problems of intercultural coexistence. 


\section{Procedure}

First of all the questionnaire was translated into the different languages of the respective countries: Spanish, Hungarian and Czech, following the guidelines of Muñiz and Hambleton (1996). We then made a random selection of schools from each country, whose teachers would be applied the Questionnaire on Difficulties for School Coexistence. Once we had made the selection, we contacted the Headteachers and Directors of Studies at each school to obtain their consent, and proceeded to apply the questionnaire individually to the participating teachers.

\section{Results}

For the data analysis we transformed the four rating levels (not at all, slight, moderate and high presence) into numerical and quantitative scores, so that "not at all" corresponded to a score of 0 , "slight" to 1 , "moderate" to 2 and "high presence" to 3 . In order to see whether there were differences between the responses given by teachers from the countries analyzed (Spain, Hungary and the Czech Republic), and whether they were significant, we applied a one-factor ANOVA. This test permits us to reject the hypothesis of equality of the mean score for each country in many of the situations analyzed, since the significance level observed is under 0.05 . In order to identify the levels of the "country" variable among which these differences occur, and whether they are statistically significant, we used multiple post hoc comparisons through the Games-Howell method.

It was found, in the sample as a whole, that teachers report the problems in their school, from highest to lowest frequency, as follows (Figure 1): fights, insults and demotivation/boredom, there are groups which don't get on, no clear norms of coexistence, pupils think the teachers don't understand them, bad language in class, conflicts between pupils and teachers, problems of intercultural coexistence, there are pupils who are not integrated and feel alone, teachers just go about their own business, use or presence of weapons, and use or presence of drugs.

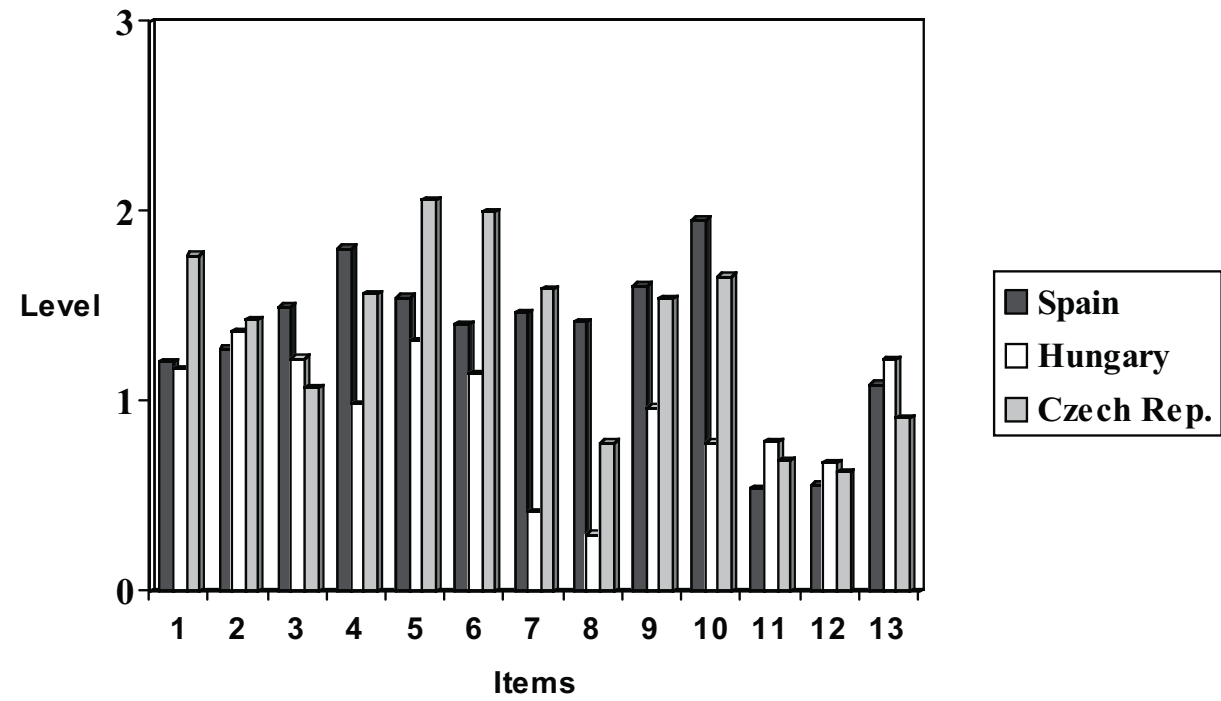

Figure 1. Means. Prevalence of problems

Note. 1: conflicts between pupils and teachers; 2: no clear norms of coexistence; 3: bad language in class; 4: pupils insult one another; 5: pupils fight; 6 : there are groups which don't get on; 7 : there are pupils who are not integrated and feel alone; 8: teachers just go about their own business; 9: pupils think the teachers don't understand them; 10: pupils are demotivated/bored; 11: use or presence of weapons; 12: use or presence of drugs; 13: problems of intercultural coexistence. 
This order changes when teachers are asked how they are personally affected by each one of these aspects (Figure 2). This time the order, from highest to lowest frequency, is: demotivation/boredom, problems of intercultural coexistence, use or presence of weapons, use or presence of drugs, fights, insults, pupils think the teachers don't understand them, there are groups which don't get on, no clear norms of coexistence, conflicts between pupils and teachers, bad language in class, there are pupils who are not integrated and feel alone, and teachers just go about their own business.
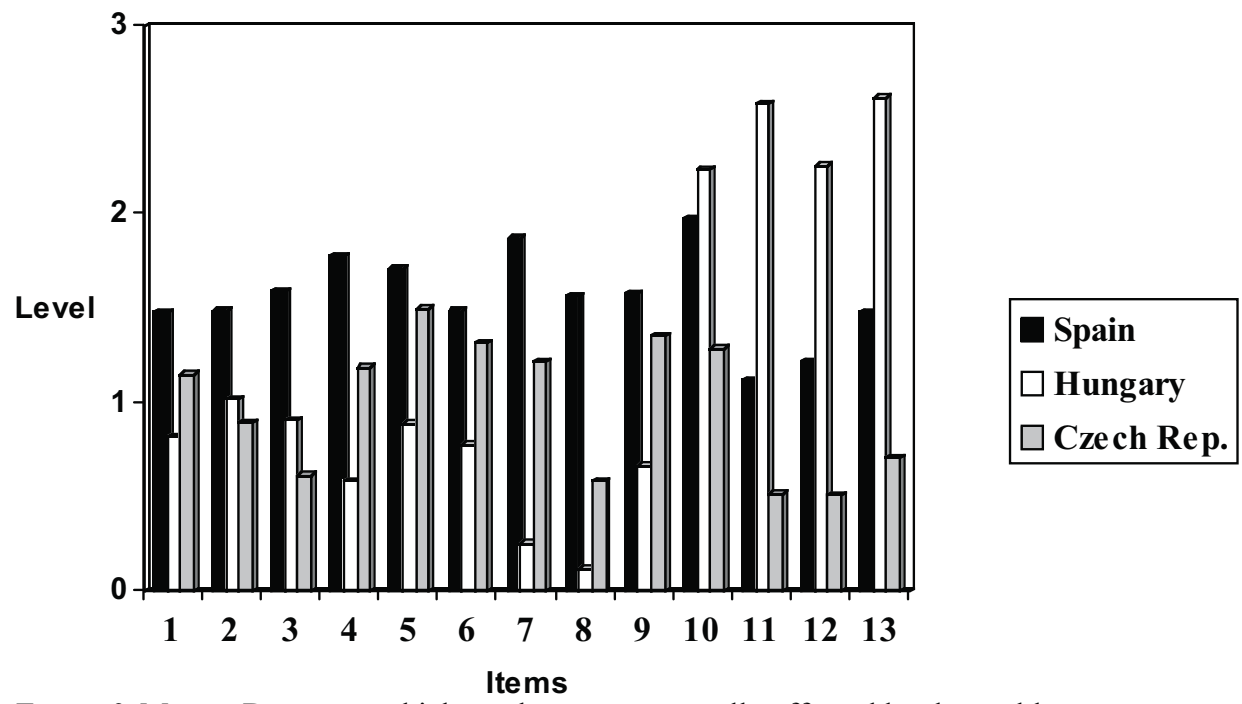

Figure 2. Means. Degree to which teachers are personally affected by the problem

Note. 1: Conflicts between pupils and teachers; 2: no clear norms of coexistence; 3 : bad language in class; 4: pupils insult one another; 5: pupils fight; 6 : there are groups which don't get on; 7: there are pupils who are not integrated and feel alone; 8: teachers just go about their own business; 9: pupils think the teachers don't understand them; 10: pupils are demotivated/bored; 11: use or presence of weapons; 12: use or presence of drugs; 13: problems of intercultural coexistence.

As can be seen in Table 1, the results of the ANOVA reveal the significance level observed in each case, whose value is always less than .05, except in two cases referring to prevalence (Table 1): lack of clear norms of coexistence, whose intergroup quadratic mean is $.634(F=.894$ and Sig.=.410), and use or presence of drugs, whose intergroup quadratic mean is $.517(F=.979$ and Sig.=.377). In the rest of the cases we can speak of intergroup differences between the mean scores for teachers from the different countries. It is therefore necessary to apply the GamesHowell method to reveal the countries between which these differences occur.

As it can be seen in Table 2, the teachers from Spain consider pupils' demotivation/ boredom, insults, pupils think the teachers don't understand them, fights and bad language in class as the commonest aspects. Hungarian teachers present lower values in comparison with those of the other two countries, and consider the commonest aspects to be lack of clear norms of coexistence (similar to Spain and the Czech Republic), fights (considerably below the Czech Republic), problems of intercultural coexistence (slightly above the Czech Republic), bad language in class, and conflicts between pupils and teachers (similar to Spain). Teachers from the Czech Republic, meanwhile, list fights, groups which don't get on and conflicts between pupils and teachers as the aspects most frequently found in their schools, with ratings in all three cases above those of Spain and Hungary. 
Table 1

Prevalence of problems and degree to which teachers are personally affected by the problem. Descriptive statistics and ANOVA

\begin{tabular}{|c|c|c|c|c|c|c|c|c|c|}
\hline \multirow[b]{2}{*}{$\mathrm{T}_{\mathrm{T}}$} & \multirow[b]{2}{*}{ P!.my } & \multicolumn{4}{|c|}{ 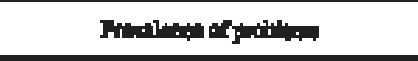 } & \multicolumn{4}{|c|}{ 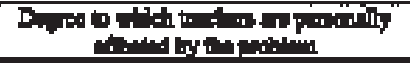 } \\
\hline & & $\mathbf{T}$ & g. & 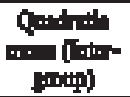 & 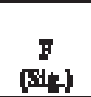 & $\mathbf{M}$ & 8 & 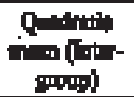 & $\underset{\text { [iftry }}{\text { F }}$ \\
\hline \multirow{5}{*}{ | } & 89 & 125 & $.7 \pi$ & \multirow{5}{*}{$7 g a$} & \multirow{5}{*}{$\begin{array}{l}14+43 \\
(100)\end{array}$} & 110 & 1FH & \multirow{4}{*}{13749} & \multirow{4}{*}{ 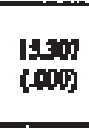 } \\
\hline & Ents & 50 &.$\pi r^{2}$ & & & 11 & $.7 \pi 3$ & & \\
\hline & t: & 3 & 87 & & & H & .73 & & \\
\hline & TI & 酯 & $7 H$ & & & Fis & .pH & & \\
\hline & $5: 1$ & I3 & 1年 & & & 15 & I표 & & \\
\hline \multirow{4}{*}{ 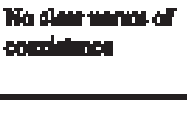 } & En:Y & En & Al & \multirow{3}{*}{ St4 } & \multirow{3}{*}{ Hido } & 131 & 대넌 & \multirow{3}{*}{ IQR日. } & \multirow{3}{*}{ I } \\
\hline & (4.tha & क & .THS & & & $\theta$ & קיח & & \\
\hline & $\mathrm{T}+1$ & 宝 & 표 & & & $3 i$ & .97 & & \\
\hline & gath & IST & 5 & \multirow{4}{*}{4.28} & \multirow{4}{*}{$\begin{array}{l}1.24 \\
\text { (000) }\end{array}$} & 174 & 1.I. & & \\
\hline \multirow{4}{*}{ طانس } & gnisty & 130 & 5 & & & 111 & . 1 & & 思直1 \\
\hline & tht.t. & 9 & 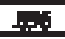 & & & 1. & $\pi$ & $\sin$ & $(400)$ \\
\hline & T..... & ES & (15 & & & 74 & 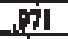 & & \\
\hline & Fi. & 135 & 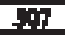 & & & 13 & $1 \mathrm{ft}$ & & \\
\hline Popt & 7. Iי r & F! & \$1 & 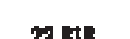 & T.694 & 14 & .4 & & t5164 \\
\hline mot & 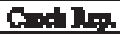 & 6 & 5 & EHI & conos & 4 & 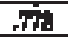 & HWS & thos \\
\hline & $\mathrm{T}-1$ & 폰ㄷ & 8 & & & 声 & 1011 & & \\
\hline & 6 & FE & 15.1 & & & TFit & I.T. & & \\
\hline & ER:y & 190 & 5.4 & & 20,04, & 17 & 데 & & 224 \\
\hline & ㄴ. pras & $\mathrm{O}$ & .TID & 1739 & (ano) & $\square$ & .74 & 214 & (NOD) \\
\hline & $\mathrm{T}=\mathrm{d}$ & 대내 & .71. & & & 7낸ㄷ & $M$ & & \\
\hline & Si & 115 & ㄷ. 모 & & & 15 & 152 & & \\
\hline & B..." tr & $1 \geqslant 0$ & $M$ & $14 \mathrm{~m}$ & tovi & 172 & II & 17 n & M1106 \\
\hline 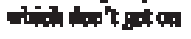 & 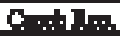 & 4 & 84 & 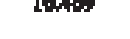 & (000) & A & 67 & IPIIt & onot \\
\hline & I: & $\pm \underline{5}$ & 4 & & & 垃 & +4 & & \\
\hline T. & E:1 & $\mathbf{E S}$ & $m$ & & & $1 \pm$ & 17 & & \\
\hline its & זיקי & $1 \mathbf{E 0}$ & sIL & & I06945 & $1+4$ & MI & 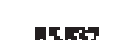 & IEspon \\
\hline & thPan & D & 매 & Whas & (noto) & $\square$ & 5 & Whint & (otot) \\
\hline In & $\left.T_{t}\right]$ & ㄱㄴ논 & 5 & & & 211 & $11 \%$ & & \\
\hline & $\mathrm{gr+1}$ & I0I & 5 & & & 14 & Ins & & \\
\hline & 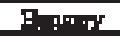 & 17 & 74 & 147 & 的 40 & 13 & 34 & 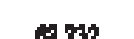 & IOA6503 \\
\hline 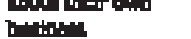 & 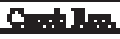 & $y$ & St. & 20301 & (noto) & $y$ & +13 & Ences & (ADO) \\
\hline & Id & 24 & 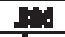 & & & 25 & 10ll & & \\
\hline & 51 & LE & $\sqrt{6}$ & & & $1 \pm$ & 5 & & \\
\hline$t$ & 표 r r & EN & 뎨 & $151:$ & $\mathbf{7 5 . 1 1 5}$ & It1 & m & 78 & 39484 \\
\hline & Gdn & $\phi$ & ta & thine & pooto & 田 & 51 & domese & (NOO) \\
\hline & $T$ & 宝4 & 15 & & & In & 모도 & & \\
\hline & E.? & FE & 77 & & & 114 & 5 & & \\
\hline Folp & F-nth & It: & 5 & & I01.91: & 1t노 & 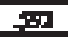 & & 포맥 \\
\hline tathod & 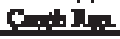 & 9 & 호돈 & A & $4000)$ & 9 & $\sqrt{1})$ & Al & (10DO) \\
\hline & TL..: & 24 & MA & & & 王5 & 5 & - & \\
\hline & $5 !$ & 136 & in & & & 13 & 114t & & \\
\hline Unap, of & 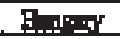 & IE & 519 & 710 & 4915 & 1 1도 & 5 & & 14:45 \\
\hline mL & Gdth & 어 & 4 & 2154 & (nis) & H & 奥 & IIstan & Hoto \\
\hline & $\mathrm{7}=1$ & 포난 & 76 & & & 实5 & 12 & & \\
\hline & है & ES & $\mathrm{Br}$ & & & 15 & $12 \overline{1}$ & & \\
\hline 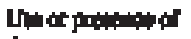 & 하메 다 & Lo & rts & 77 & $M$ & 19 & $\sqrt{14}$ & & I.4: \\
\hline & trin Res & 65 & $\mathbf{P}$ & 317 & $(5 \pi)$ & 7 & .7. & 7073 & $(000)$ \\
\hline & Tthl & 710 & 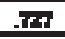 & & & 7.1 & 11. & & \\
\hline & 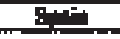 & 155 & 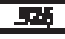 & & & 17 & 17 & & \\
\hline 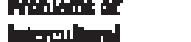 & 프는 & Lo & ت5 & fot: & 935 & 1호 & 노1 & an: & 10,67 \\
\hline & tinging & 19 & .1. & 2016 & (b) & 9 & 71 & Hots & cotot \\
\hline & Tth & 囸 & 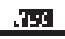 & & & 7it & 1.1圆 & & \\
\hline
\end{tabular}


The Spanish teachers coincide with those from the Czech Republic in considering as the least frequent aspects the use or presence of weapons and use or presence of drugs, and the Czech teachers add problems of intercultural coexistence to these two. In the first two cases, scores are similar to those given by the Hungarian teachers, but they give even lower scores significantly lower than those given by the Spaniards and Czechs - to "teachers just go about their own business" and "there are pupils who are not integrated and feel alone".

Table 2

Prevalence of problems. Games-Howell method

\begin{tabular}{|c|c|c|c|c|c|c|}
\hline Ту & Cantrina & of & Centin & 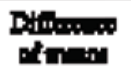 & Connen & 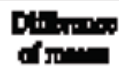 \\
\hline 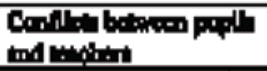 & H & $|09|$ & 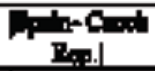 & grive & R. & 160\% \\
\hline 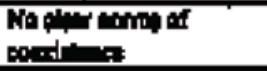 & & |0영 & & ㄴ1ㅕㅕ & & 10: \\
\hline E- & & | & 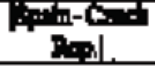 & $14 z_{1}$ & & 1,$19 ;$ \\
\hline 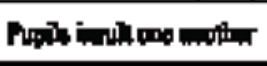 & & 191\%" & & $|24|$ & & |Nㅐ \\
\hline Puplin Aly: & & |.1이 & & $|51| \mu$ & & |rop/ \\
\hline 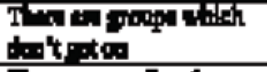 & & |2:0" & Palden & 15: & & 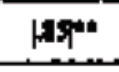 \\
\hline 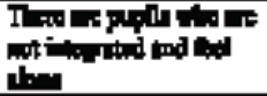 & & $|1,04|$ & Fonim- & |ll1 & & |1.19후 \\
\hline 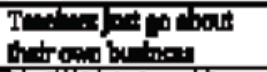 & & $1.12 \mathrm{~m}$ & Inter & LGi & & $|\boldsymbol{A T T}|^{* *}$ \\
\hline 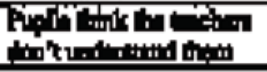 & & $163 \mid+*$ & 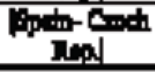 & 107 & 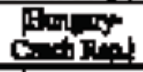 & 1594" \\
\hline 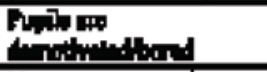 & & |1.19* & 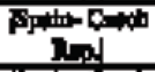 & $\left|p_{y}\right|$ & & b팝 \\
\hline 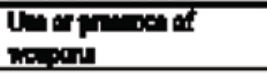 & & | & 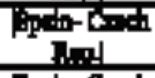 & H.19 & & ㄴ14 \\
\hline 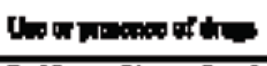 & & |1. & ind & Lor & 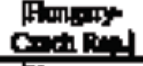 & In: \\
\hline 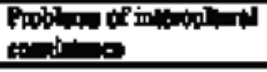 & 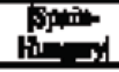 & |12: & 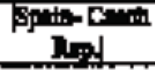 & $|17|$ & |lintis & 13\% \\
\hline
\end{tabular}

Note. *The difference of means is significant to a level of $.05 ; * *$ The difference of means is significant to a level of .01 .

As can be seen in Table 3, teachers' ratings change when they are asked about the extent to which they are personally affected by each aspect. Once again, the teachers from Hungary present the lowest scores, except in the four items they consider to affect them most, to which they give higher scores than those from Spain and the Czech Republic: problems of intercultural coexistence, use or presence of weapons, pupils' demotivation/boredom and use or presence of drugs.

The Spanish teachers highlight pupils' demotivation/boredom (similar score to Hungary), there are pupils who are not integrated and feel alone, insults and fights, with the last three aspects scoring higher than Hungary and the Czech Republic. As regards the Czech teachers, they give the highest scores to fights (higher than Hungary), pupils think the teachers don't understand them (similar to Spain and above Hungary), groups that don't get on (similar to Spain) and pupils' demotivation/boredom (below Hungary and Spain). 
Table 3

Degree to which teachers are personally affected by the problem. Games-Howell method

\begin{tabular}{|c|c|c|c|c|}
\hline 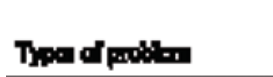 & C. chiste & of of & Difines & 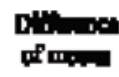 \\
\hline דin & & 66in & 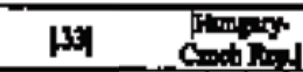 & $\mid \mathbf{F}^{*}$ \\
\hline 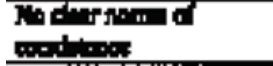 & & $|n| * \mid$ & 151 & HII \\
\hline 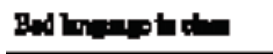 & & $|6| * \mid$ & 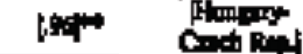 & |rsp \\
\hline 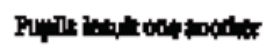 & & 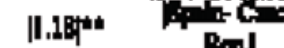 & קוt & Lw⿻ \\
\hline 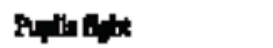 & & | & 124 & 16 en \\
\hline 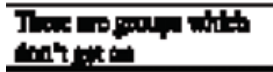 & & r & p19 & 15:40 \\
\hline 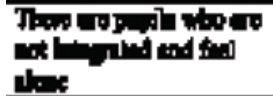 & & |1.51|" & Ifin & 1964 \\
\hline 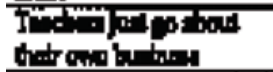 & & |LAOH" & $\mid \boldsymbol{H}_{\boldsymbol{1}}$ & $|n| r \mid$ \\
\hline 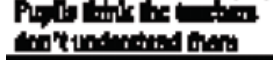 & & 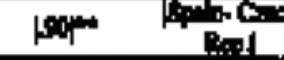 & ||| & |esp \\
\hline 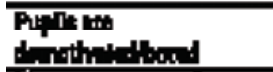 & & 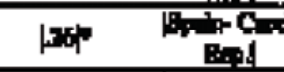 & 16in & F \\
\hline 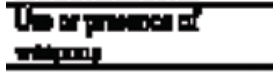 & & $\mid 1,4 \pi^{* 4}$ & p대 & porl \\
\hline 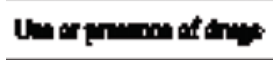 & & ||0.04" & $\ln r$ & |1.74 \\
\hline م: & & $|1.18| * \mid$ & IN⿴囗十⺝ & 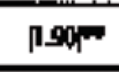 \\
\hline
\end{tabular}

Note. ${ }^{*}$ The difference of means is significant to a level of .05; **The difference of means is significant to a level of .01 .

\section{Discussion}

Teachers highlight fights, insults, pupils' demotivation/boredom, groups that don't get on and the lack of clear norms of coexistence as the problem aspects most common in their schools, and these are followed by insults, an aspect considered in many previous studies in this field (Olweus, 1999; Peets \& Kikas, 2006; Spanish People's Ombudsman's Report, 2000) as the main problem affecting secondary schools. Along with verbal abuse, other studies have also reported social exclusion as one of the commonest problem aspects (Kim, Koh, \& Leventhal, 2004).

It may not be valid to compare teachers' perception with that of pupils, since many studies indicate a discrepancy between them, suggesting that teachers tend to report more cases of abuse than pupils, especially when they are asked about the school as a whole and not just their own class (Cangas, Gázquez, Pérez, Padilla, \& Miras, 2007; Gázquez, Cangas, Pérez, Padilla, \& Cano, 2007; Spanish People's Ombudsman's Report, 2000) - that is, when they are not assessing their personal context of activity. This may be due to teachers' denial of the problem (Sullivan, 2000), or, as Rigby (1996) argues, in a similar line, to the fact that teachers have scarce knowledge of the problems or conflicts that occur and of how these affect the victims. Therefore, we consider, in accordance with Yoon (2004), that future research should include and compare the opinions of the two groups.

As expected, when asked about how they are affected personally, teachers give low scores to the item "teachers just go about their own business", but when they are asked about 
how common this aspect is in the school, scores are higher (high prevalence); that is, when they refer not only to their own behaviour but also to that of other teachers, the prevalence of this phenomenon rises, except in Hungary, where analysis of the scores shows that teachers consider it the least common aspect and that which least affects them.

Comparison between the scores given by teachers from the different countries in the two dimensions (prevalence of the aspects in their schools and personal repercussions), for each one of the aspects considered, reveals that in Spain the two coincide, with highest scores (thus indicating highest perceived prevalence and personal repercussions) being given to pupils' demotivation/boredom; this should lead teachers to introduce new and more creative activities in their classes with a view to eliminating the problem (Hong, Lawrenz, \& Veach, 2005). Likewise, the Czech teachers perceive fights between pupils as both the aspect most prevalent and that which most affects them personally.

Such a coincidence is also found for all three countries (Spain, Czech Rep. and Hungary) in the aspect perceived as least prevalent and with least personal repercussion: use or presence of weapons in Spanish schools, teachers just go about their own business in Hungarian schools and use or presence of drugs in Czech schools. However, such coincidence is not found in Hungarian teachers, who perceive lack of clear norms of coexistence as the commonest aspect in their schools, but problems of intercultural coexistence that which most affects them personally.

Nevertheless more studies tosupport these results are needed. They must enable us to see if the differences among the different countries are truly representative of the countries involved or are under the influence of the countries involved (or are under the influence of the selected sample). On equal terms it would the wise to complete the sample with other countries to properly analyze its evolution (Due et al., 2005; Smith et al., 1999).

\section{References}

Cangas, A.J., Gázquez, J.J., Pérez, M.C., Padilla, D., \& Miras, F. (2007). Evaluación de la violencia escolar y su afectación personal en una muestra de estudiantes europeos. Psicothema, 19(1), 114-119.

Chapell, M., Casey, D., De la Cruz, C., Ferrell, J., Forman, J., Lipkin, R., Newsham, M., Sterling, M., \& Whittaker, S. (2004). Bullying in college by students and teachers. Adolescence, 39, 53-64.

Crothers, L.M., \& Levinson, E.M. (2004). Assessment of bullying: A review of methods and instruments. Journal of Couseling and Development, 82, 496-503.

Dake, J.A., Price, J.H., Telljohann, S.K., \& Funk, J.B. (2003). Teacher perceptions and practices regarding school bullying prevention. The Journal of School Health, 79(9), 347-355.

Due, P., Holstein, B.E., Lynch, J., Diderichsen, F., Gabhain, S.N., Scheidt, P., \& Currie, C. (2005). Bullying and symptoms among school-aged children: International comparative cross sectional study in 28 countries. The European Journal of Public Health, 15, 128-132.

Espelage, D.L., \& Swearer, S.M. (2003). Research on school bullying and victimization: What have we learned and were do we go from here? School Psychology Review, 32(3), 365-383.

Fekkes, M., Pijpers, F.I.M., \& Verloove-Vanhorick, S.P. (2005). Bullying: Who does what, when and were? Involvement of children, teachers and parents in bullying behavior. Health Education Research, 20(1), 81-91.

Fisher, K., \& Kettl, P. (2003). Teachers' perceptions of school violence. Journal of Pediatric Health Care, 17, 79-83.

Gázquez, J.J., Cangas, A.J., Padilla, D., Cano, A., \& Pérez-Moreno, P.J. (2005). Assessment by pupils,teachers and parents of school coexistence problems in Spain, France, Austria and Hungary: Global psychometric data. International Journal of Psychology and Psychological Therapy, 5(2), 101-112.

Gázquez, J.J., Cangas, A.J., Pérez, M.C., Padilla, D., \& Cano, A. (2007). Percepción de la violencia escolar por parte de los familiares: Un estudio comparativo en cuatro países europeos. International Journal of Clinical and Health Psychology, 7, 93-105. 
Griffin, R.S., \& Gross, A.M. (2004). Childhood bullying: Current empirical findings and future directions for research. Aggression and Violent Behavior, 9, 379-400.

Hong, Z., Lawrenz, F., \& Veach, P.M. (2005). Investigating perceptions of gender education by students and teachers in Taiwan. The Journal of Educational Research, 98(3), 156-163.

Juvonen, J., Graham, S., \& Schuster, M.A. (2003). Bullying among young adolescents: The strong, the weak, and the troubled. Pediatrics, 112(6), 1231-1237.

Kim, Y.S., Koh, Y.J., \& Leventhal, B.L. (2004). Prevalence of school bullying in Korean middle school students. Archives of Pediatrics \& Adolescent Medicine, 158(8), 737-741.

Krug, E.G., Dahlberg, L.L., Mercy, J.A., Zwi, A.B., \& Lozano, R. (2002). World report on violence and health. Geneva: World Health Organization.

Meyer, H.A., Astor, R.A., \& Behre, W. (2002). Teachers' reasoning about school violence: The role of gender and location. Contemporary Educational Psychology, 27, 499-528.

Muñiz, J., \& Hambleton, R.K. (1996). Directrices para la traducción y adaptación de los test [Indications for translating and adapting psychological tests]. Papeles del Psicólogo, 66, 63-70.

Newman-Carlson, D., \& Horne, A.M. (2004). Bully busters: A psychoeducational intervention for reducing bullying behavior in middle school students. Journal of Counseling and Development, 82(3), 259-267.

Olweus, D. (1999). Sweden. In P.K. Smith, Y. Morita, J. Junger-Tas, D. Olweus, R. Catalana, \& P. Slee (Eds.),. The Nature of School Bullying. A cross national perspective (pp. 7-28). London: Routledge.

Orpinas, P., Horne, A.M., \& Multisite Violence Prevention Proyet. (2004). A teacher-focused approach to prevent and reduce students' aggressive behavior. The GREAT teacher program. American Journal of Preventive Medicine, 26(1S), 29-38.

Ortega, R., \& del Rey, R. (2003). La violencia escolar: Estrategias de prevención [School violence: Strategies and prevention]. Barcelona: Graó.

Peets, K., \& Kikas, E. (2006). Aggressive strategies and victimization during adolescence: Grade and gender differences, and cross-informant agreement. Aggressive Behavior, 32, 68-79.

Rigby, K. (1996). Bullying in schools: And what to do about it. London: Jessica Kingsley.

Smith, P.K., Morita, Y., Junger-Tas, J., Olweus, D., Catalano, R., \& Slee, P. (1999). The nature of school bullying. A cross-national perspective. London: Routledge.

Smith-Khuri, E., Iachan, R., Scheidt, P.C., Overpeck, M.D., Gabhainn, S.N., Pickett, W., \& Harel, Y. (2004). A crossnational study of violence-related behaviors in adolescents. Archives of Pediatrics \& Adolescence Medicine, 158, 539-544.

Solberg, M.E., \& Olweus, D. (2003). Prevalence estimation of school bullying with the Olweus Bully/Victim Questionnaire. Aggressive Behavior, 29, 239-268.

Spanish People's Ombudsman's Report (2000). Informe sobre violencia escolar: El maltrato entre iguales en la educación secundaria obligatoria [Report on school violence: Abuse among peers in secondary education]. Madrid: Publicaciones de la Oficina del Defensor del Pueblo.

Sullivan, K. (2000). The anti-bullying handbook. Auckland: Oxford University Press.

Yoon, J.S. (2004). Predicting Teacher Interventions in Bullying Situations. Education \& Treatment of Children, 27(1), $37-45$.

L'objectif de cette étude a été de faire connaître la perception qu'a le professorat de trois pays européens (Espagne, Hongrie et République Tchèque) de la prévalence et de la capacité d'affecter personnellement de divers aspects affectant la vie en commun scolaire. Les résultats montrent une grande prévalence de disputes, insultes et démotivation/ennui des élèves, selon les enseignants de ces pays. Cependant, ils signalent aussi en tant qu'aspect qui les affecte 
personnellement le plus, la démotivation/ennui des élèves filles et garçons. Par ordre de pays, ce sont l'Espagne et la République Tchèque qui présentent les taux les plus élevés de violence scolaire, la Hongrie venant après de manière significative. On trouve aussi des différences dans les trois pays analysés quant à la prévalence et à la capacité d'affecter des divers problèmes de vie en commun scolaire étudiés.

Key words: Bullying, Coexistence in schools, School violence, Teachers.

Received: July 2006

Revision received: May 2007

José Jesús Gázquez Linares. Dpto. Psicología Evolutiva y de la Educación, Facultad de Psicología y Ciencias de la Educación, Universidad de Almería, Carretera Sacramento S/N, 04120 Almería, España. E-mail: jlinares@ual.es; Web site: www.ual.es

Current theme of research:

Bullying. Learning strategies in secondary-school pupils.

Most relevant publications in the field of Psychology of Education:

Cangas, A.J., Pérez, M.C., \& Gázquez, J.J. (2006). Factor de impacto de las publicaciones españolas de psicologia utilizando un amplio rango de revistas fuente. International Journal of Psychology and Psychological Therapy, $6(3), 417-424$.

Cangas, A.J., Gázquez, J.J., Pérez, M.C., Padilla, D., \& Miras, F. (2007). Evaluación de la violencia escolar y su afectación personal en una muestra de estudiantes europeos. Psicothema, 19(1), 114-119.

Gázquez, J.J., Cangas, A.J., Padilla, D., Cano, A., \& Pérez-Moreno, P.J. (2005). Assessment by pupils, teachers and parents of school coexistence problems in Spain, France, Austria and Hungary: Global psychometric data. International Journal of Psychology and Psychological Therapy, 5(2), 101-112.

Gázquez, J.J., Cangas, A.J., Pérez, M.C., Padilla, D., \& Cano, A. (2007). Percepción de la violencia escolar por parte de los familiares: Un estudio comparativo en cuatro países europeos. International Journal of Clinical and Health Psychology, 7(1), 93-105.

Gázquez, J.J., Pérez, M.C., Ruiz, M.I., Miras, F., \& Vicente, F. (2006). Estrategias de aprendizaje en estudiantes de enseñanza secundaria obligatoria y su relación con la autoestima. International Journal of Psychology and Psychological Therapy, 6(1), 51-62.

Adolfo Javier Cangas Díaz. Dpto. Psicología Personalidad y Tratamiento Psicológicos, Facultad de Psicología y Ciencias de la Educación, Universidad de Almería, Carretera Sacramento S/N, 04120 Almería, España. E-mail: ajcangas@ual.es; Web site: www.ual.es

Current theme of research:

Bullying. Mental health problems in the schools.

Most relevant publications in the field of Psychology of Education:

Cangas, A.J., Errasti, J.M., García, J.M., Álvarez, R., \& Ruiz, R. (2006). Metacognitive factors and alterations of attention related to predisposition to hallucinations. Personality and Individual Differences, 40, 487-496. 
Cangas, A.J., Gázquez, J.J., Padilla, D., Fuentes, M.C., \& Miras, F. (2007). Evaluación de la violencia escolar y su repercusión personal en una muestra de estudiantes europeos. Psicothema, 19(1), 114-119.

Gázquez, J.J., Cangas, A.J. Padilla, D., Cano, A., \& Pérez-Moreno, P. (2005). Assessment by pupils, teachers and parents of school coexistence problems in Spain, France, Austria and Hungary: Global psychometric data. International Journal of Psychology and Psychological Therapy, 5(2) 101-112.

Gázquez, J.J., Cangas, A.J. Pérez, M.C., Padilla, D., \& Cano, A. (2007). Percepción de la violencia escolar por parte de los familiares: Un estudio comparativo en cuatro países europeos. Internacional Journal of Clinical and Health Psychology, 7(1), 93-105.

Olivencia, J.J., \& Cangas, A.J. (2003). Las adicciones en adolescentes. Claves para prevenirlas y afrontarlas: Una guía para padres. Málaga. Arguval (Reeditado en 2005 por la Editorial Panamericana. Bogotá: Colombia).

María del Carmen Pérez Fuentes. Dpto. Psicología Evolutiva y de la Educación, Facultad de Psicología y Ciencias de la Educación, Universidad de Almería, Carretera Sacramento S/N, 04120 Almería, España. E-mail: congralm@ual.es; Web site: www.ual.es

Current theme of research:

Bullying. Learning strategies in secondary-school pupils.

Most relevant publications in the field of Psychology of Education:

Cangas, A.J., Pérez, M.C., \& Gázquez, J.J. (2006). Factor de impacto de las publicaciones españolas de psicologia utilizando un amplio rango de revistas fuente. International Journal of Psychology and Psychological Therapy, $6(3), 417-424$.

Cangas, A.J., Gázquez, J.J., Pérez, M.C., Padilla, D., \& Miras, F. (2007). Evaluación de la violencia escolar y su afectación personal en una muestra de estudiantes europeos. Psicothema, 19(1), 114-119.

Gázquez, J.J., Cangas, A.J., Pérez, M.C., Padilla, D., \& Cano, A. (2007). Percepción de la violencia escolar por parte de los familiares: un estudio comparativo en cuatro países europeos. International Journal of Clinical and Health Psychology, 7(1), 93-105.

Gázquez, J.J., Pérez, M.C., Ruiz, M.I., Miras, F., \& Vicente, F. (2006). Estrategias de aprendizaje en estudiantes de enseñanza secundaria obligatoria y su relación con la autoestima. International Journal of Psychology and Psychological Therapy, 6(1), 51-62.

Francisca Lucas Acién. Dpto. Psicología Evolutiva y de la Educación, Facultad de Psicología y Ciencias de la Educación, Universidad de Almería, Carretera Sacramento S/N, 04120 Almería, España. E-mail: flucas@ual.es; Web site: www.ual.es

Current theme of research:

Bullying. Learning strategies in secondary-school pupils.

Most relevant publications in the field of Psychology of Education:

Gázquez, J.J., Pérez, M.C., \& Lucas, F. (in press). Valoración de la dependencia mediante la aplicación de una Escala de Capacidad Funcional para Mayores. International Journal of Psychology and Psychological Therapy, 8(1).

Gázquez, J.J., Pérez, M.C., Miras, F., Yuste, N., Lucas, F., \& Ruiz, M.D. (2007). Análisis y satisfacción del Servicio de Ayuda a Domicilio en la provincia de Almería. Anales de Psicología, 23(1), 101-108. 